\title{
Endemics and endangered species in the biodiversity hotspot of the Shada Mountains, Saudi Arabia
}

\author{
Jacob THOMAS ${ }^{1 *}$, Mohamed A EL-SHEIKH ${ }^{1,2}$, Abdulrehman A ALATAR $^{1}$ \\ ${ }^{1}$ Department of Botany \& Microbiology, College of Science, King Saud University, Riyadh 11451, Saudi Arabia; \\ ${ }^{2}$ Botany Department, Faculty of Science, Damanhour University, Damanhour 22516, Egypt
}

\begin{abstract}
Shada Mountains in Saudi Arabia, separated by Maleel Wadi into twin mountains (i.e., Shada Alalah and Shada Asfal), are rich in biodiversity. We investigated the diversity of endemics and endangered species of the mountains based on the data collected from 38 stands falling in 8 elevational zones ranging from 500 to $2215 \mathrm{~m}$ a.s.l. Results indicated that 495 plant species falling in 314 genera and 76 families occurred in the Shada Mountains, including 19 endemic species and 43 endangered species, and accounting for $22 \%$ of the total flora in Saudi Arabia. Canonical correlation analysis indicated that physiographic features, particularly altitude play an important role in the frequency and abundance of species. Endemics were not evenly distributed in the Shada Mountains and mostly restricted in the elevation zone of 1000-1500 or $>1500 \mathrm{~m}$ a.s.l. When the altitude reached up to $2000 \mathrm{~m}$ a.s.l., the endemics decreased substantially due to the significantly low temperature. The endangered species existed three different distribution patterns: (i) most endangered species distributed in the altitudes of 1000-1800 $\mathrm{m}$ a.s.l.; (ii) endangered trees, lianas, and shrubs occupied the altitudes 1000-1300 $\mathrm{m}$ a.s.l.; and (iii) endangered subshrubs and herbs inhabited the altitudes 1500-2100 $\mathrm{m}$ a.s.l. The results demonstrated that the biodiversity of endangered species in the Shada Mountains is high and undisturbed by invasive species, and protective measures should be taken against human disturbances to the small-scale hotspot.
\end{abstract}

Keywords: elevational gradient; invasion; Shada Alalah; Shada Asfal; Wadi Jof

Citation: Jacob THOMAS, Mohamed A EL-SHEIKH, Abdulrehman A ALATAR. 2017. Endemics and endangered species in the biodiversity hotspot of the Shada Mountains, Saudi Arabia. Journal of Arid Land, 9(1): 109-121. doi: $10.1007 / \mathrm{s} 40333-016-0025-8$

\section{Introduction}

Hotspots with heterogeneous habitats and high species diversity are often targeted areas for the conservation. As a rule, species richness or biodiversity normally increases with altitudes where moisture level is high (Hall et al., 2009, 2010). It means that the high altitudes in arid areas are most likely the hotspots with heterogeneous habitats and high species diversity. However, the biodiversity within the relatively vulnerable ecosystems in arid areas has been greatly threatened by a variety of factors including climate change and human activities (Zhang and Ma, 2008). Thus, relevant physiographic data (e.g., soil characteristics and altitudinal regimes) of different spatial scales are badly needed for assessing the severity of the threat to biodiversity (Miller and Nyberg, 1991; Beard et al., 2000; Ojeda et al., 2000). Different models have been put forward to explain the observed heterogeneity of endemics in their distribution patterns (Roberts et al., 2002) and

*Corresponding author: Jacob THOMAS (E-mail: jathomas@ksu.edu.sa)

Received 2016-02-24; revised 2016-04-15; accepted 2016-05-03

(C) Xinjiang Institute of Ecology and Geography, Chinese Academy of Sciences, Science Press and Springer-Verlag Berlin Heidelberg 2017 
spatial analysis and geostatistics were often combined with those models to identify the endemics-hyperspaces for prioritizing the conservation efforts (Whittaker et al., 2005; Dewidar and Al Rehili, 2013). However, many remains to be known about the endemics-hyperspaces along altitudinal transects in arid areas.

Despite the fact that Arabian Peninsula, within which Saudi Arabia is situated, has been subjected to botanical explorations since Forsskål (1775), a comprehensive flora list of Saudi Arabia was achieved much later with the efforts of Migahid (1978), Collenette (1999), Chaudhary (1999-2001), and Thomas et al. $(2014,2015)$. A number of publications (Ghazanfar and Fisher, 1998; Hegazy et al., 1998; Chaudhary and Al-Jowaid, 1999; Hall et al., 2011; El-Sheikh et al., 2013; Alatar et al., 2015) provided a great deal of details on the composition and the density of plant species and also on the status of endemic and endangered plant species in Saudi Arabia. However, our knowledge on the biodiversity of small spatial scales is generally lacking and our knowledge on the biodiversity at different altitudes is particularly lacking. Nevertheless, this kind of knowledge is a necessity for prioritizing the efforts in conserving mountain ecosystems of arid areas. Saudi Arabia possesses 16 protected areas and nearly 30 sites are currently under consideration of designating as "plant biodiversity hotspots" (Hall et al., 2011; Llewellyn et al., 2011). The Shada Mountains range is one such area with rich diversity in terms of both species diversity and species abundance, and the information with the needed details is not yet available. The aim of this study was to investigate the diversity and the distribution of endemic and endangered plant species along an altitudinal transect and to evaluate the impact of physiographic factors on the diversity in the Shada Mountains.

\section{Materials and methods}

\subsection{Study area}

The Shada Mountains range is composed of Shada Alalah and Shada Asfal with the peak altitudes of 2215 and $1472 \mathrm{~m}$ a.s.l., respectively $\left(15^{\circ} 41^{\prime}-15^{\circ} 42^{\prime} \mathrm{N}, 47^{\circ} 19^{\prime}-55^{\circ} 19^{\prime} \mathrm{E}\right)$. The twin mountains (Shada Alalah and Shada Asfal) are separated by Wadi Meleel valley. The Shada Alalah is a chain of hills that forms a continuous elevated crest and the Shada Asfal is a relatively gentle-sloped mountain (Figs. 1a-c). Influenced by topography and air currents coming from the Red Sea, the climate is cooler and wetter at higher altitudes than in the lowlands. Average annual precipitation is $148.7 \mathrm{~mm}$ with a monthly mean ranging from $1.5 \mathrm{~mm}$ in February to $37.5 \mathrm{~mm}$ in April. Monthly mean temperature ranges from $9.0^{\circ} \mathrm{C}$ in January to $36.5^{\circ} \mathrm{C}$ in August. Humidity varies from $59 \%$ in January to $24 \%$ in June.

\subsection{Data collection}

\subsubsection{Sampling}

Plant specimens were collected from eight elevational zones in the twin mountains during 2013-2015 and the eight elevational zones were: 500-1000 m (EZ-1), 1001-1200 m (EZ-2), 1201-1400 m (EZ-3), 1401-1600 m (EZ-4), 1601-1800 m (EZ-5), 1801-2000 m (EZ-6), 2001-2200 m (EZ-7), and 2201-2215 m (EZ-8) above sea level. Two notes need mentioning here: (1) the elevation spanning from 500 to $800 \mathrm{~m}$ was merged into EZ-1 because the area (i.e., 500-800 $\mathrm{m}$ a.s.1.) is poorly vegetated and is devoid of any endemic and endangered plants, and (2) EZ-8 (2201-2215 m a.s.l.) is the rocky summit portion of Shada Alalah and also poorly vegetated. Thirty eight (38) phytosociological stands (i.e., plots) were selected to assess the population density of endemic and endangered plants. Stands (i.e., plots) with each of $50 \mathrm{~m} \times 50 \mathrm{~m}$ were selected in such a way that it contains population of at least one endangered species or endemic species. The used nomenclature of species is in accordance to Chaudhary (1999-2001), Wood (1997) and Collenette (1999). Published literature pertaining to the status of species in Saudi Arabia was referenced and the status of the plants (endemic or endangered) was verified by Collenette (1999). Not all endemics were considered for density analysis because many intraspecies taxa (e.g., Aloe and Asclepias) occurred in some genera (Chaudhary, 1999-2001). 


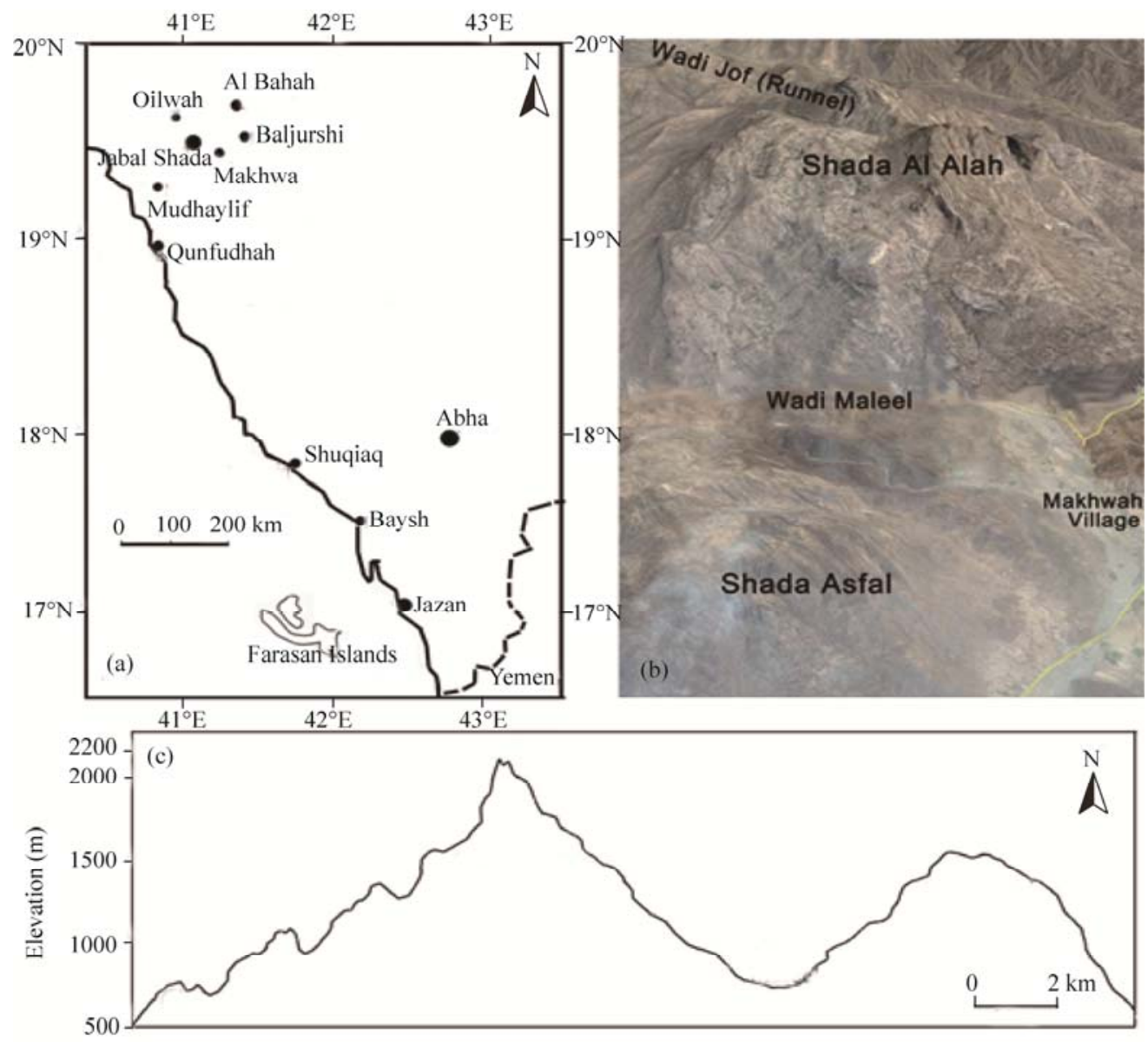

Fig. 1 (a) Map showing Shada Mountains and the surroundings in eastern Saudi Arabia; (b) Satellite view of the Shada Mountains (i.e., twin mountains); and (c) Schematic representation of a cross section of the twin mountains.

\subsubsection{Analysis of floristic data}

The field-collected data included 323 species (46 trees, 96 shrubs, 105 subshrubs, 21 perennial grasses, 46 herbs, and 9 annual grasses) that were taken from 38 stands and were subjected to diversity analysis. Our results were also compared with those from other hotspots or regions from Saudi Arabia (e.g., southwestern, northwestern, central, and eastern provinces) to examine the status of endemic and endangered plant species from a larger geographic perspective. Data of these hotspots were obtained mostly from herbarium (KSU) database or from technical reports (Llewellyn, 2010, 2011).

\subsubsection{Soil analysis}

Three soil samples were collected at a depth of $0-50 \mathrm{~cm}$ from each of the 38 stands and each sample was well mixed before laboratory analyses to ensure the uniformity. Soil organic matter content was measured using soil ignition method. Soil texture was determined using hydrometer method. Electrical conductivity (EC) and $\mathrm{pH}$ were determined in 1:5 soil/water ratios. The methods of soil analysis were referenced from Allen et al. (1989).

\subsubsection{Human impact assessment}

Three-level scheme proposed by El-Sheikh $(2005,2013)$ was adopted to assess the human impacts: Level-1 (low, $\leq 10 \%$ ), Level-2 (moderate, 11\%-30\%), and Level-3 (extreme, $\geq 30 \%$ ). Level-1 stands were situated along steep slopes with rather dense vegetation and negligible human disturbance. Level-2 stands included those that were not severely disturbed by soil erosion, grazing and trampling. Level-3 stands characterized by relatively severe disturbances of human 
activities including grazing, picnicking, and trekking.

\subsubsection{Data analysis}

Density, frequency, abundance and their relative values of endemic and endangered plant species were calculated based on the number of plant individuals in each stand. The vegetation and soil characteristics of 19 endemics and 43 endangered species that were taken from 38 stands were subjected to multivariate analysis using canonical correlation analysis (CCA; Braak and Šmilauer, 2002). Species richness ( $\alpha$-diversity) was calculated as the average number of species/stands.

Shannon-Wiener index $H=-\sum_{i=1}^{s} p_{i} \log p_{i}$ for relative evenness and Simpson index $C=\sum_{i=1}^{s} p_{i}^{2}$ for the concentration of dominance were calculated for each stand on the basis of the relative cover $p_{i}$ of the $i^{\text {th }}$ species (Pielou, 1975; Magurran, 1988). The inter-relationships among such variables as ordination axes, vegetation characteristics, soil characteristics were established using Pearson's linear correlation coefficient $(r)$. The linear relationships among such variables as altitude, endemic/endangered plants, diversity, and habitat were analyzed using the SPSS15.0 software (SPSS, 2006).

\section{Results}

Flora of the Shada Mountains is composed of 495 species falling in 314 genera, 76 families, and twelve (12) and two (2) of these 495 species belong to pteridophytes and gymnosperms, respectively. Poaceae and Asteraceae are the largest families with 67 and 44 species, respectively, followed by Leguminosae (28 spp.) and Malvaceae (24 spp.). The Shada Mountains contained $3.8 \%$ endemic species and $13.4 \%$ endangered species. We also compared our results with those from other hotspots or regions in Saudi Arabia to examine the status of endemics and endangered species from a larger geographic perspective (Table 1). For example, in the southwestern and southern regions, Jabal Fayfa had 2.8\% endemic species and $10.4 \%$ endangered species; Raydah Escarpments, 3.4\% endemic species and 10.2\% endangered species. Wadi Dessah, another hotspot in the northwestern and northern regions with a strong influence of Mediterranean floristic elements, contained $2.5 \%$ endemic species and $13.1 \%$ endangered species, being the second to Shada Mountains (13.4\%) in terms of endangered species. Among the 19 endemic species in Table 2, shrubs were the highest ( 9 spp.), followed by subshrubs (6 spp.), herbs ( 3 spp.) and trees (1 spp.). Forty-three (43) endangered species (17 shrubs, 12 subshrubs, herbs, and trees 7 each) accounted for $6.6 \%$ of the total endangered species in Saudi Arabia (Table 3). Tropical families (e.g., Acanthaceae, Anacardiaceae, Burseraceae, Moraceae, Rubiaceae and Sapotaceae) accounted almost half of the total species in the country.

\subsection{Species diversity along elevational zones (EZ)}

\section{EZ-1 (500-1000 m a.s.l.)}

Wadi Maleel valley and its tributaries separate Shada Mountains into two mountains, i.e., Shada Alalah and Shada Asfal. The seasonal river in Wadi Maleel flows from east to west and support some semi-aquatic species such as Bacopa monnieri, Calendula arvensis, etc. The vegetation in the river bed was dominated by Acacia ehrenbergiana, A. tortilis, Calotropis procera, etc. and occasionally by Hyphaene thebaica and Delonix elata. The vegetation around large boulders was dominated by $A$. etbaica, Hyparrhenia hirta, Solanum incanum, etc. Endemic and endangered taxa were practically absent in this zone. Overall, vegetation on the rocky slopes flanking the wadi and its tributaries was dominated by ruderal plants including Calotropis procera, Nicotiana glauca and Opuntia dellenii.

\section{EZ-2 (1001-1200 m a.s.l.)}

This zone had the highest percent of endemic and endangered species, being one of the high diversity areas in the Shada Mountains. The vegetation was mostly composed of Acacia asak, 
Table 1 A comparison of the diversity of endemics and endangered species among different hotspots in Saudi Arabia

\begin{tabular}{|c|c|c|c|c|}
\hline Regions/Hotspot & $\begin{array}{l}\text { Area } \\
\left(\mathrm{km}^{2}\right)\end{array}$ & $\begin{array}{l}\text { Total } \\
\text { species }\end{array}$ & $\begin{array}{c}\text { Endemics } \\
(\%)\end{array}$ & $\begin{array}{l}\text { Endangered } \\
\text { species (\%) }\end{array}$ \\
\hline \multicolumn{5}{|l|}{ Southwestern and southern regions } \\
\hline Jabal Shada & 68.62 & 495 & 3.8 & 13.4 \\
\hline Jabal Fayfa & 120 & 537 & 2.8 & 10.4 \\
\hline Raydah Escarpments & 9.33 & 519 & 3.4 & 10.2 \\
\hline Southern Tihama (Tihamat Asir) & 24,000 & 360 & 1.9 & 4.4 \\
\hline Island flora (Red Sea Islands) & 5408 & 202 & 0.9 & 6.9 \\
\hline \multicolumn{5}{|l|}{ Northwestern and northern regions } \\
\hline Harrat Al-Harra & 13,775 & 218 & 1.8 & 8.3 \\
\hline Wadi Dessah & 160,000 & 160 & 2.5 & 13.1 \\
\hline Northern Tihama (Tihamat Al-Hejaz) & 10,000 & 258 & 1.6 & 2.3 \\
\hline \multicolumn{5}{|l|}{ Central region } \\
\hline Raudhat Khuraim & 45 & 153 & - & 2.6 \\
\hline Jabal Aja \& Salma & 2000 & 285 & 1.4 & 6.3 \\
\hline Ibex Reserve, Howtha Bani Tamim & 1840.9 & 263 & 1.9 & 2.3 \\
\hline \multicolumn{5}{|l|}{ Eastern region } \\
\hline Island flora (Arabian Gulf) & 145 & 85 & - & - \\
\hline
\end{tabular}

Table 2 Endemics in the Shada Mountains

\begin{tabular}{|c|c|c|c|}
\hline Species & Family & Life form & Population density \\
\hline Acacia abyssinica & Fabaceae & Tree & Moderate \\
\hline Adenium obesum & Apocynaceae & Shrub & High \\
\hline Angolluma commutata & Apocynaceae & Subshrub & Poor \\
\hline Anisotes trisulcus & Acanthaceae & Shrub & High \\
\hline Asperagus setaceus & Asparagaceae & Shrub & Moderate \\
\hline Barleria bispinosa & Acanthaceae & Shrub & High \\
\hline Barleria trispinosa & Acanthaceae & Shrub & Moderate \\
\hline Centaurothamnus maximus & Asteraceae & Shrub & Poor \\
\hline Cynoglossum bottae & Apocynaceae & Subshrub & Moderate \\
\hline Indigofera trita subsp. subulata & Fabaceae & Shrub & Poor \\
\hline Kickxia pseudoscoparia & Plantaginaceae & Subshrub & Poor \\
\hline Parietaria umbricola & Urticaceae & Herb & Poor \\
\hline Plectranthus asirensis & Lamiaceae & Shrub & High \\
\hline Reichardia tingitana var. arabica & Asteraceae & Herb & Moderate \\
\hline Rhynchosia variegata & Fabaceae & Subshrub & Poor \\
\hline Sarcostemma arabicum & Apocynaceae & Shrub & Moderate \\
\hline Silene asirensis & Caryophyllaceae & Herb & Poor \\
\hline Swertia woodii & Gentianaceae & Subshrub & Poor \\
\hline $\begin{array}{l}\text { Trichodesma trichodesmoides var. } \\
\text { discolor }\end{array}$ & Boraginaceae & Subshrub & Moderate \\
\hline
\end{tabular}

Ficus vasta and Grewia tembensis. The recorded endemic species included Acacia abyssinica, Adenium obesum, Barleria bispinosa, Indigofera trita subsp. subulata, Kickxia pseudoscoparia, Plectranthus asirensis, etc., and the recorded endangered species included Aneilema forsskalii, Boscia angustifolia, Commicarpus ambiguus, Coptosperma graveolens, Diospyros mespiliformis, Ehretia obtusifolia, Ochna inermis, etc.

\section{EZ-3 (1201-1400 m a.s.l.)}

Flora in this zone was mostly composed of tropical trees, shrubs, and lianas. The recorded endemic species included Barleria bispinosa, Rhynchosia variegata and Trichodesma trichodesmoides var. discolor, and the recorded endangered species included Myrsine africana, Portulaca kermisiana, Pavonia glechomifolia and Pollichia campestris. Acacia asak dominated in the lower portion of this zone was accompanied by the associated species such as A. hamulosa, 
Table 3 Endangered species in the Shada Mountains

\begin{tabular}{|c|c|c|c|c|c|c|}
\hline Species & Family & Life form & Chorotype & Threat & $\begin{array}{l}\text { Impact } \\
\text { of threat }\end{array}$ & Status \\
\hline Abrus precatorius & Fabaceae & Shrub & SM & A,B & 1 & EN \\
\hline Abutilon ramosum & Malvaceae & Shrub & SM & $\mathrm{B}, \mathrm{D}$ & 1 & VU \\
\hline Angolluma commutata & Apocynaceae & Subshrub & SM & $\mathrm{B}$ & 2 & VU \\
\hline Aneilema forsskalii & Commelinaceae & Herb & SM & $\mathrm{B}, \mathrm{C}$ & 2 & $\mathrm{EN}$ \\
\hline Asperagus setaceus & Asparagaceae & Shrub & TR-AF & $\mathrm{B}, \mathrm{C}$ & 2 & EN \\
\hline Blepharis maderaspatensis & Acanthaceae & Subshrub & TR-AF & $\mathrm{B}$ & 2 & EN \\
\hline Boscia angustifolia & Capparaceae & Tree & SM & $\mathrm{B}$ & 2 & $\mathrm{CR}$ \\
\hline Breonadia salicina & Ribiaceae & Tree & TR-AF & $\mathrm{A}, \mathrm{C}$ & 2 & $\mathrm{CR}$ \\
\hline Capparis tomentosa & Capparaceae & Shrub & $\mathrm{SM}$ & $\mathrm{C}$ & 2 & CR \\
\hline Caralluma petrae & Apocynaceae & Subshrub & SM & $\mathrm{B}$ & 2 & $\mathrm{EN}$ \\
\hline Ceropegia vignaldiana & Apocynaceae & Subshrub & SM & B & 1 & $\mathrm{EN}$ \\
\hline Cocculus hirsutus & Menispermaceae & Shrub & TR-AF & $\mathrm{B}, \mathrm{C}$ & 1 & EN \\
\hline Commicarpus ambiguus & Nyctaginaceae & Subshrub & SM & $\mathrm{B}$ & 2 & VU \\
\hline Coptosperma graveolens & Ribiaceae & Tree & SM & $\mathrm{B}, \mathrm{C}$ & 2 & CR \\
\hline Croton lobatus & Euphorbiaceae & Herb & SM & $\mathrm{B}$ & 1 & EN \\
\hline Diospyros mespiliformis & Ebenaceae & Tree & SM & A,B & 2 & VU \\
\hline Ehretia obtusifolia & Boraginaceae & Tree & SM & $\mathrm{B}, \mathrm{D}$ & 2 & $\mathrm{EN}$ \\
\hline Euphorbia inaequilatera & Euphorbiaceae & Shrub & SM & $\mathrm{B}, \mathrm{C}$ & 2 & $\mathrm{EN}$ \\
\hline Filago pyramidata & Asteraceae & Herb & MED-IT & $\mathrm{B}, \mathrm{E}$ & 1 & VU \\
\hline Gymnema sylvestris & Apocynaceae & Shrub & $\mathrm{TR}$ & $\mathrm{B}, \mathrm{C}$ & 1 & $\mathrm{CR}$ \\
\hline Indigofera trita subsp. subulata & Fabaceae & shrub & SM & $\mathrm{B}, \mathrm{C}$ & 1 & $\mathrm{EN}$ \\
\hline Indigofera volkensii & Fabaceae & Shrub & SM & $\mathrm{B}, \mathrm{C}, \mathrm{D}$ & 1 & EN \\
\hline Lepidagathis calycina & Acanthaceae & Subshrub & SM & $\mathrm{C}, \mathrm{D}, \mathrm{F}$ & 1 & $\mathrm{EN}$ \\
\hline Linum usitatissimum & Linaceae & Herb & MED & $\mathrm{B}, \mathrm{C}, \mathrm{D}$ & 2 & $\mathrm{EN}$ \\
\hline Megalochlamys violacea & Acanthaceae & Shrub & SM & $\mathrm{C}, \mathrm{D}, \mathrm{F}$ & 1 & $\mathrm{CR}$ \\
\hline Melhania velutina & Malvaceae & Shrub & SM & $\mathrm{B}, \mathrm{C}, \mathrm{D}$ & 2 & $\mathrm{EN}$ \\
\hline Minuartia filifolia & Caryophyllaceae & Subshrub & SM & $\mathrm{C}, \mathrm{D}, \mathrm{F}$ & 2 & VU \\
\hline Myrsine africana & Myrsinaceae & Tree & TR-AF & $\mathrm{C}, \mathrm{D}$ & 2 & $\mathrm{CR}$ \\
\hline Ochna inermis & Ochnaceae & Shrub & TR-AF & C,D & 2 & $\mathrm{CR}$ \\
\hline Osyris quadripartita & Santalaceae & Shrub & MED & $\mathrm{C}, \mathrm{D}$ & 2 & EN \\
\hline Pavonia procumbens & Malvaceae & Subshrub & TR-AF & $\mathrm{C}, \mathrm{D}$ & 2 & EN \\
\hline Pegolettia senegalensis & Asteraceae & Herb & SM & $\mathrm{C}, \mathrm{D}, \mathrm{F}$ & 1 & $\mathrm{EN}$ \\
\hline Pollichia campestris & Caryophyllaceae & Shrub & TR-AF & $\mathrm{A}, \mathrm{F}, \mathrm{G}$ & 2 & EN \\
\hline Portulaca grandiflora & Portulacaceae & Herb & TR-AF & $\mathrm{B}, \mathrm{C}, \mathrm{E}$ & 1 & VU \\
\hline Portulaca kermesina & Portulacaceae & Herb & TR-AF & $\mathrm{B}, \mathrm{C}, \mathrm{E}$ & 1 & VU \\
\hline Rhus abyssinica & Anacardiaceae & Shrub & SM & $\mathrm{C}, \mathrm{D}$ & 2 & $\mathrm{EN}$ \\
\hline Rhus natalensis & Anacardiaceae & Shrub & $\mathrm{SM}$ & C,D & 2 & $\mathrm{EN}$ \\
\hline $\begin{array}{l}\text { Scutallaria rubicunda subsp. } \\
\text { subvelutinum }\end{array}$ & Lamiaceae & Subshrub & $\mathrm{SM}$ & $\mathrm{B}, \mathrm{C}, \mathrm{D}$ & 1 & EN \\
\hline Senecio lyratus & Asteraceae & Subshrub & SM & $\mathrm{B}, \mathrm{C}, \mathrm{F}$ & 1 & VU \\
\hline Silene asirensis & Caryophyllacaee & Subshrub & SM & $\mathrm{B}, \mathrm{C}, \mathrm{E}$ & 1 & $\mathrm{EN}$ \\
\hline Vigna macrorhyncha & Fabaceae & Subshrub & TR-AF & $\mathrm{C}, \mathrm{D}$ & 1 & VU \\
\hline Woodfordia fruticosa & Lythraceae & Shrub & SM & $\mathrm{C}, \mathrm{D}$ & 2 & $\mathrm{CR}$ \\
\hline Ziziphus mucronata & Rhamnaceae & Tree & TR-AF & $\mathrm{C}, \mathrm{F}$ & 2 & $\mathrm{CR}$ \\
\hline
\end{tabular}

Note: MED, Mediterranean; MED-IT, Mediterrannean-Irano-Turanian; SM, Somali-Masai; TR-AF, Tropical Africa. A, road development; B, eroded soil; C, poor seed production and germination; D, low moisture; E, habitat loss; F, invasive species encroachment; 1, decline in population size; 2, very small population/very restricted distribution; CR, critically endangered; EN, endangered; VU, vulnerable. 
Cordia senensis, Ficus ingens and Grewia villosa. In sunny areas, surface was covered by grasses such as Cenchrus ciliaris, Setaria viridis, Hyparrhenia hirta, etc. In granite massif-exposed rocky slopes, the vegetation was scarce with sporadically-distributed endemic plant Adenium obesum and Acacia etbaica species.

\section{EZ-4 (1401-1600 m a.s.l.)}

Within this elevation, this zone is characterized by steep terrains in the Shada Alalah and by a large plateau in the Shada Asfal and was dominated by Acacia asak and Barbeya oleoides. Six endemic species (Adenium obesum, Angolluma commutata, Anisotes trisulcus, Barleria bispinosa, B. trispinosa and Sarcostemma arabicum) were recorded, of which Ademium obesum was found in all stands of this zone. Approximately 10 endangered species and 2 critically endangered species (Breonadia salicina and Capparis tomentosa) were recorded, mostly from the plateau of Shada Asfal.

\section{EZ-5 (1601-1800 m a.s.l.)}

Endemics and endangered species were scarcely distributed in this zone. Three (3) endemic species and five (5) endangered species were recorded in this zone and they included Ficus cordata subsp. salicifolia-Cenchrus ciliaris-Indigofera spinosa community and the associated species (e.g., Barbeya oleoides and Acacia asak). Among the endemics, the Barleria bispinosa cover was the highest, followed by Adenium obesum and Sarcostemma arabicum.

\section{EZ-6 (1801-2000 m a.s.l.)}

Vegetation density in this zone was high and most species distributed on the slopes of the Shada Alalah. The dominated plants are: Dodonaea angustifolia, Olea europaea, Psiadia punctulata and the associated Rhus abyssinica, Cenchrus ciliaris and Barbeya oleoides. Totally, four (4) endemics and endangered species were recorded in this zone.

\section{EZ-7 (2001-2200 m a.s.l.)}

Species was moderate in abundance with high taxonomic singularity. Endemics and endangered taxa were rare in this zone. Juniperus procera, Olea europaea and Rhus natalensis dominated the top layer; Dodonaea angustifolia, Pistacia falcata, Psiadia punctulata and Psydrax schimperiana dominated the shrub layer; and grasses such as Cenchrus ciliaris, Hyparrhenia hirta and Themeda triandra dominated the herb layer. Six (6) endemic species and five (5) endangered species were recorded in this zone, of which Plectranthus asirensis occurred in all sampled stands. Although the endemics and endangered species were low in diversity, their densities were relatively high in comparison with EZ-5 and EZ-6.

\section{EZ-8 (2201-2215 m a.s.l.)}

The steep terrains with large boulders constitute the highest zone and the zone was dominated by subshrubs and herbs such as Alyssum desertorum, Euphorbia schimperiana, Nepeta deflersiana, Plectranthus asirensis and Themeda triandra, etc.

To sum up, the proportion, cover and frequency of endemic species across life-forms were significantly different from those of the endangered species along the altitudinal transect in the Shada Mountains. Overall, shrubs and subshrubs each constituted 42.1\%. The former (shrubs) was abundant in EZ-4 while the latter (subshrubs) was in EZ-7. Herbs were found in the zones of EZ-2 and EZ-7 while the tree species was only in EZ-2. For endangered species, shrubs and trees were mostly found in EZ-2 while they were least in EZ-6. The cover of endemics was the highest in EZ-7 and the lowest in EZ-5 (Fig. 2a), while frequency was the highest in EZ-3 and the lowest in EZ-6. As for the endangered species, the highest cover and highest frequency occurred in EZ-7 and EZ-2, respectively (Fig. 2b).

Figure 3 showed the diversity and the density of endemics and endangered species at different elevational zones in the Jabal Shada. The highest diversities of these species were found in EZ-2 where ravine existed. The highest density of endemics (e.g., Adenium obesum, Barleria bispinosa and Indigofera trita subsp. subulata) occurred in EZ-3 due to the richness of tropical trees and shrubs in several runnels and along their edges and the density significantly decreased in EZ-4 (Fig. 3a). The lowest and highest species densities of endangered species occurred in EZ-3 and EZ-7, respectively, and exhibited an increasing trend with increasing elevations (Fig. 3b). 

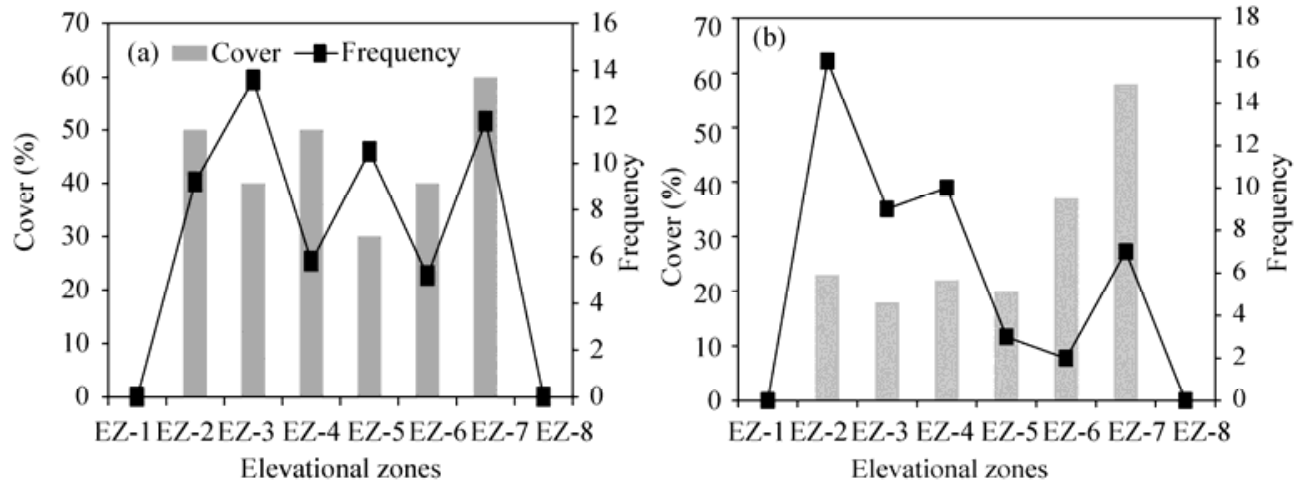

Fig. 2 Cover and frequency of endemics (a) and endangered species (b) in the Shada Mountains across different elevational zones (EZ). EZ-1, 500-1000 m; EZ-2, 1001-1200 m; EZ-3, 1201-1400 m; EZ-4, 1401-1600 m; EZ-5, 1601-1800 m; EZ-6, 1801-2000 m; EZ-7, 2001-2200 m; EZ-8, 2201-2215 m.
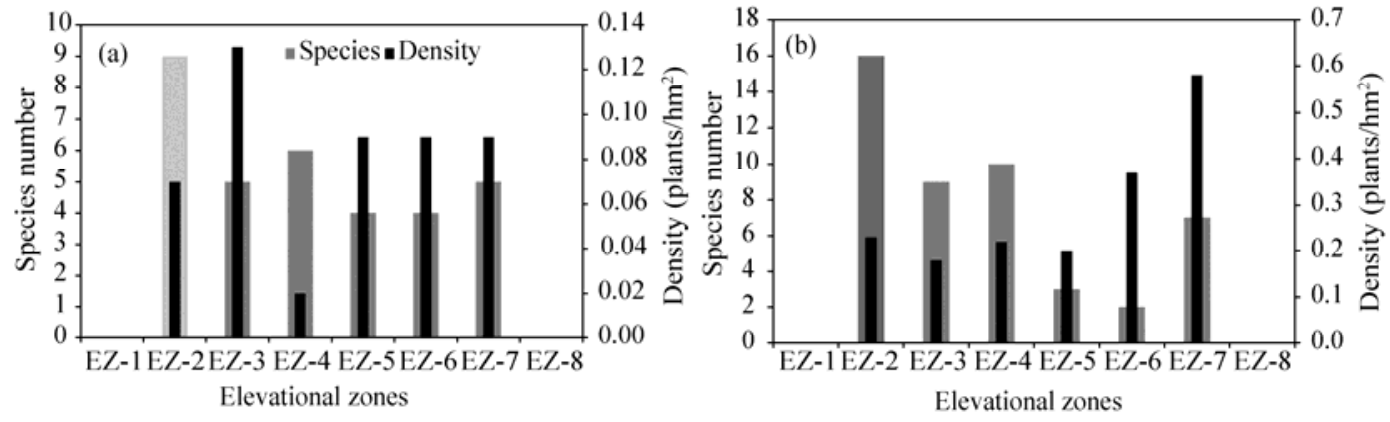

Fig. 3 Diversity and density of endemics (a) and endangered species (b) in the Jabal Shada across different elevational zones

\subsection{Relation between endemics and environmental variables}

The CCA (canonical correlation analysis) indicated that the distribution of endemic species on the Axis-1 was positively correlated with density, species number, species richness, Shannon-Wiener index and soil silt content, and negatively correlated with EZ, Simpson index and soil organic matter. Moreover, on the Axis- 2 the distribution of endemic species was positively correlated with the intensity of human impact and soil silt content, and negatively correlated with EZ and endemics density (Table 4; Fig. 4a). It means that the environmental factors determined the geographic distribution of endemics and endangered species. CCA results indicated that endemics grouping together on the right-hand side of Axis-1 occurred in the Wadi Meleel valley (e.g., stands 25 and 26) and also in other stands situated in EZ-2, EZ-4 and EZ-6 (e.g., stands 13 and 34) and they were positively correlated with species cover, density (Fig. 4b). Species clustering on the left-hand side of Axis-2 distributed in the Shada Asfal, and they were positively correlated with EC, organic matter content, $\mathrm{pH}$ and Simpson index. Species from stands (e.g., stands 8-15, 19, 35) that were situated in the higher elevations of the Shada Alalah tended to cluster together and were correlated with altitudinal levels, and soil clay and sand contents.

\subsection{Relation between endangered species and environmental variables}

The CCA indicated that the distribution of endangered species, concentrating in the ravine of low altitudes (e.g., stands 24, 25 and 26) or in slopes of high altitude (stands 8-15), was positively correlated with species evenness and human impact on the Axis-1 and Axis-2, respectively, but negatively correlated with endemics density on the Axis-2 (Table 5; Fig. 5a). The correlation analysis suggested that the separation of endangered species along Axis-1 is strongly affected by altitude, species cover, Simpson index, and density (Fig. 5b). 

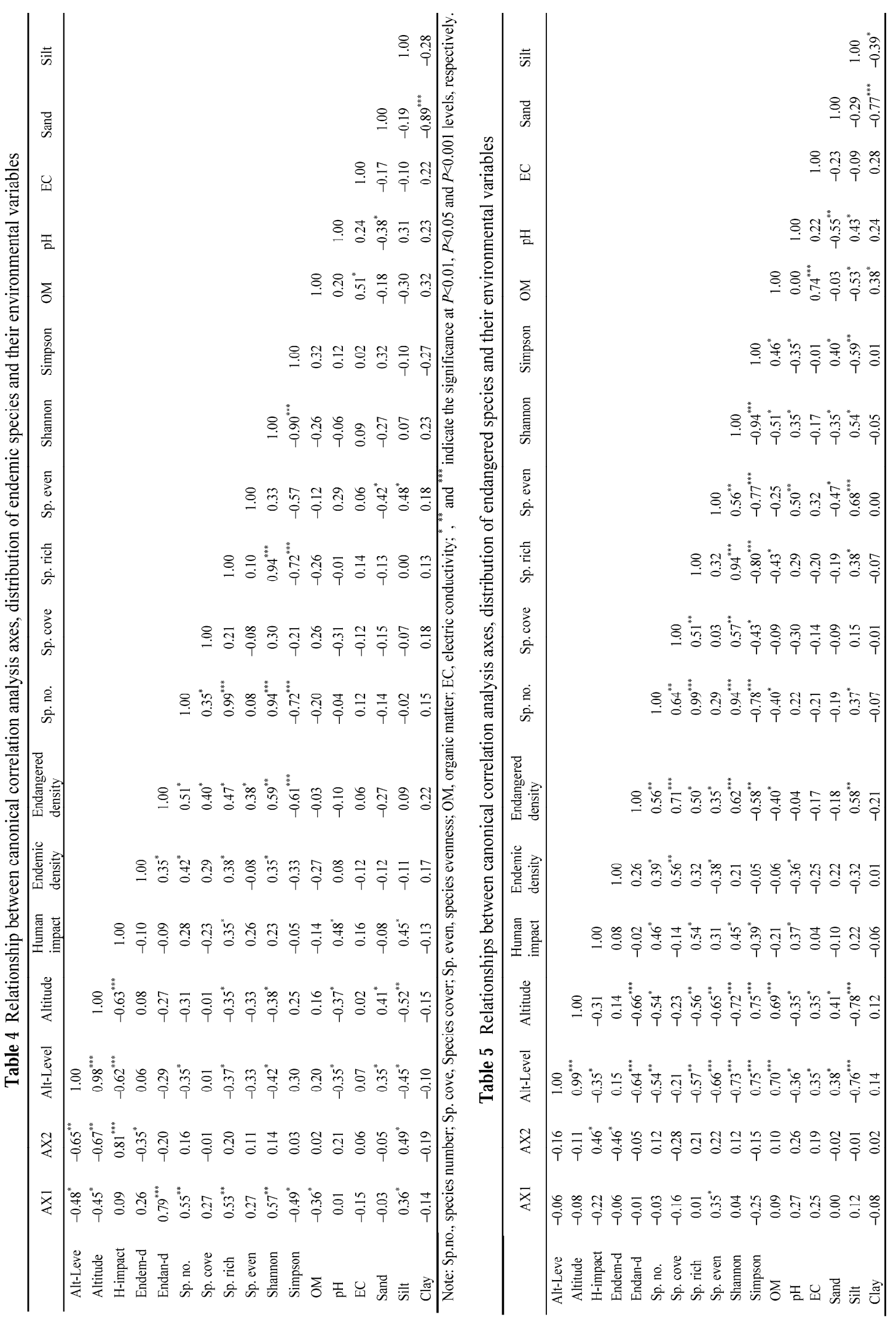

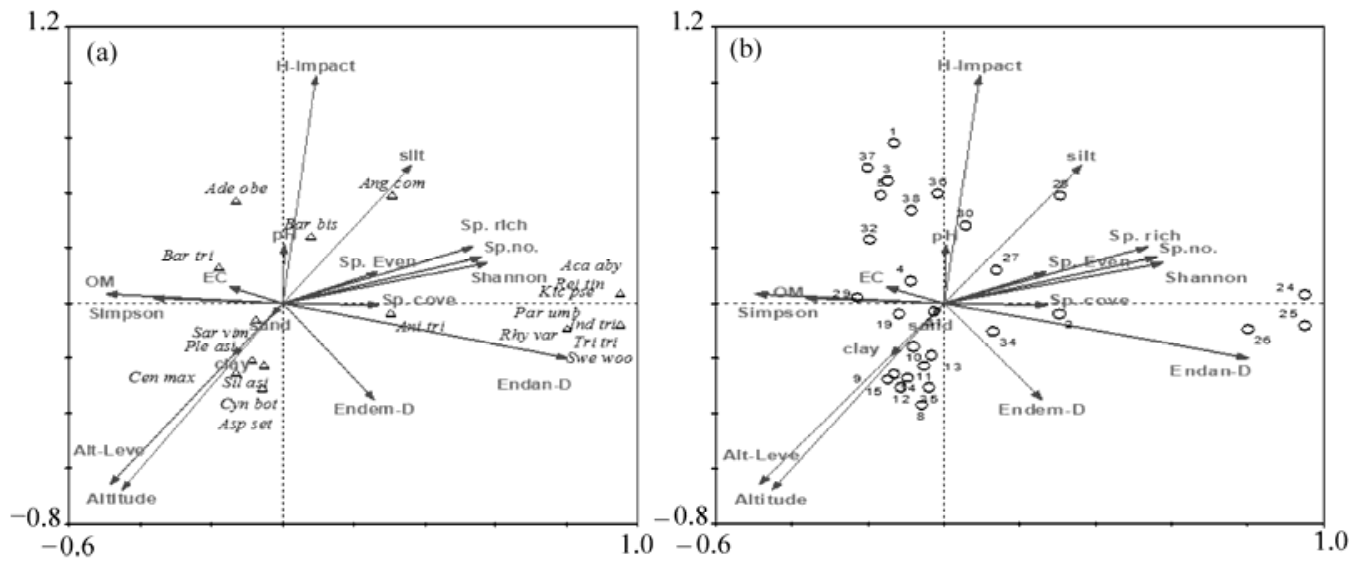

Fig. 4 Correlation biplot with environmental variables of endemics (a) and stands (b) in the study area
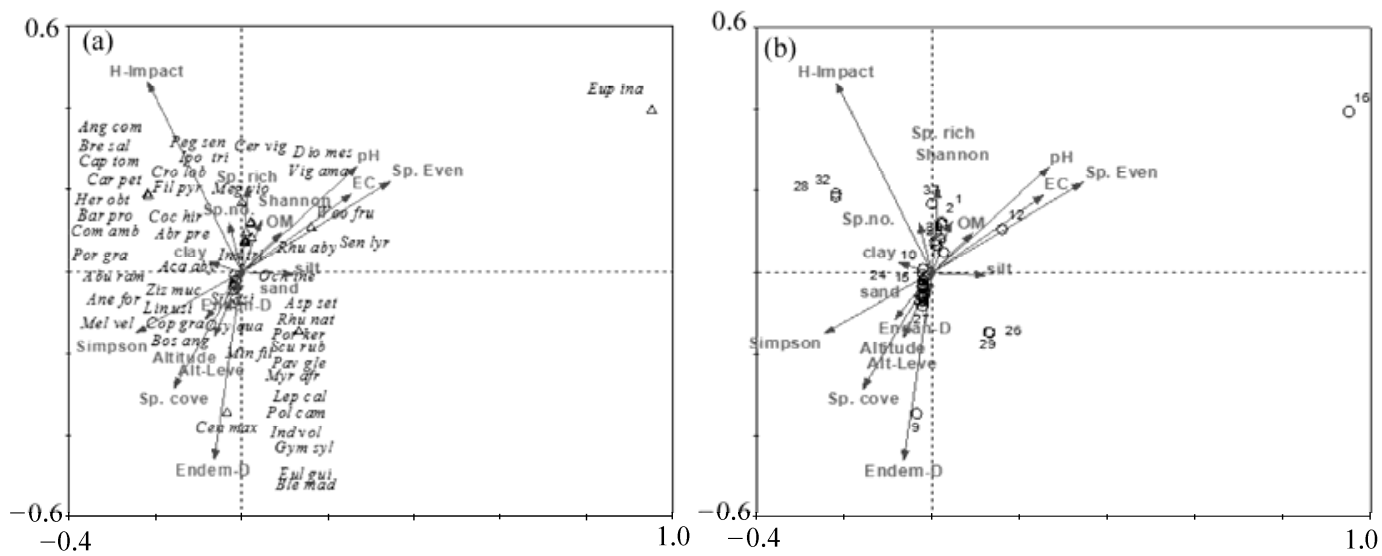

Fig. 5 Correlation biplots with environmental variables of endangered species (a) and stands (b) in the study area

\section{Discussion}

Species frequency and abundance were dependent on topographic gradient and abiotic factors, including slopes, runnels, ravines and open-top ridges. The reported decrease in species richness above the $1500 \mathrm{~m}$ a.s.l. and low diversity in higher altitudes (Colwell and Hurtt, 1994) were probably resulted from eco-physiological constraints, such as short growing season, low temperatures and low vigor of vegetation (Brown, 2001). In tropical countries, the diversity of endemic species was reportedly increased with altitudes, reached the maximum in the middle altitudes and gradually decreases towards the mountain summits (Gentry, 1986; Major, 1988). The results from this study also showed the similar trends in the Shada Mountains of Saudi Arabia.

The Shada Mountains, similar to the same altitude region of Northeast African countries (Ghazanfar and Fisher, 1998), are dominated by the families of Asteraceae, Leguminosae, Poaceae, etc. (Beard, 2000) with scarcely distributed Amaranthaceae and Chenopodiaceae. And, these plant species in Shada Mountains were considered to be solitary without external mixtures due to the absence of a migration corridor for cross-breeding. The Shada Mountains stretch across three climate zones ranging from subtropical climate at $500 \mathrm{~m}$ a.s.l., tropical climate at 1000-1500 m a.s.l. to subalpine climate above $1500 \mathrm{~m}$ a.s.l. Acacia thorn woodlands interspersing with ruderals and exotic species dominated the subtropical zone where the vegetation was significantly affected by overgrazing (Thomas et al., 2016). Barbeya oleoides, Ficus palmate and Cenchrus ciliaris dominated the tropical zone. Juniperus procera, Olea europaea subsp. 
cuspidata and shrubs such as Euryops arabicus and Psiadia puntulata dominated the subalpine zone (El Karemy and Zayed, 1992; Hegazy et al., 1998; Thomas et al., 2016).

The twin mountains, i.e., Shada Alalah and Shada Asfal, are significantly different in topography, with rather steep slopes and less rocky in the former and with relatively gentle slopes and more rocky in the latter. Therefore, vegetation coverage was lower in Shada Asfal than in Shada Alalah. Cenchrus ciliaris and xerophytes such as Adenium obesum, Klenia odora dominated in crevices and slopes of ditches in Shada Asfal. Barbeya oleoides and Ficus spp. dominated the rocky slopes of higher zones and Acacia etbaica, Barleria spp., Indigofera spinosa, etc. dominated the lower zones in Shada Asfal. The occurrence of endemic xerophytes, Adenium obesum, Barleria bispinosa and B. trispinosa along with the common I. spinosa at $1400 \mathrm{~m}$ a.s.l. altitude of the Shada Asfal suggests the microclimate in this zone is extremely arid.

Endemics were not evenly distributed in the Shada Mountains, mostly restricting in the elevation zone of 1000-1500 or $>1500 \mathrm{~m}$ a.s.l. where four endemic species were mainly confined in the Wadi Meleel river bed. When the altitude reached up to $2000 \mathrm{~m}$ a.s.l., the endemics decreased substantially due to the significantly lowered temperature (Figs. 2a and 3). A similar distribution pattern of endemics was reported in the Himalayas (Vetaas and Grytnes, 2002). Among the 19 endemics, only Silene asirensis is strictly endemic to the Saudi Arabia, all others are near-endemics and were also found in Yemen and Northeast African countries (Thulin, 1993; Wood, 1997). Unlike the results of van der Werff and Consiglio (2004), the density of endemics did not increase with elevation. Xerophytes, Adenium obesum and Barleria bispinosa were found to be negatively correlated with altitude while Plectranthus asirensis and Sarcostemma arabicum were found to be positively correlated with altitude (Fig. 6).
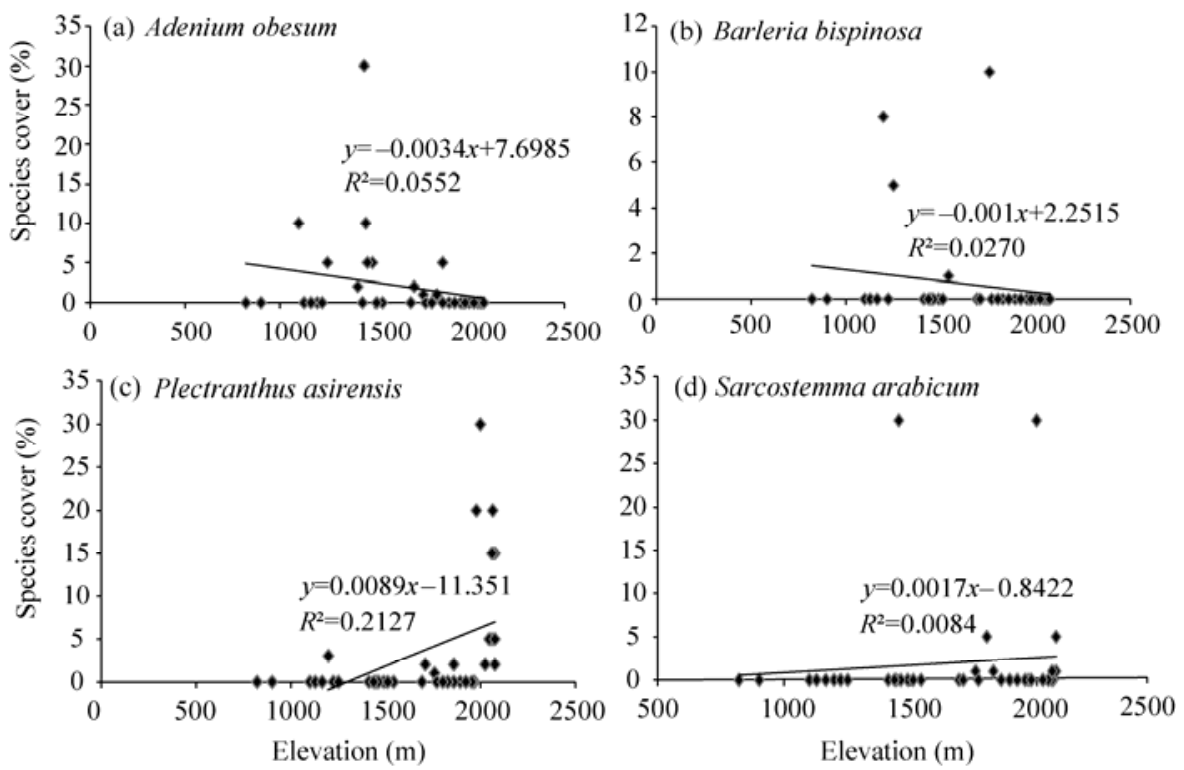

Fig. 6 Cover of important endemics across different elevations in the Shada Mountains

Endangered species in the Shada Mountains concentrated in the elevational ranges of 1001-1200 and 1401-1600 $\mathrm{m}$ a.s.1. and the highest density occurred in 2001-2200 $\mathrm{m}$ a.s.1., being consistent with the report by Hegazy et al. (1998). The habitats of those critically endangered species listed by Hall et al. (2009) were highly degraded due to the road development and other human activities in the Shada Alalah. Highly disturbed species included Breonadia salicina, Capparis tomentosa, Portulaca kermesina and Silene asirensis. However, we found that the population sizes of these endangered species have not increased during the past several decades.

Due to the topographic barriers in the Shada Mountains, invasive species were not rich and only Nicotiana glauca, Opuntia dellenii and Tagetes minuta were found at high altitudes (1401-1900 m a.s.1.). And the Opuntia dellenii has not become an invasive species in Shada 
Mountains in comparison to the Raydah Escarpments in Saudi Arabia and Sri Lanka, where the species was well established as an invasive plant (Ratnaweera et al., 2015; Thomas et al, 2016).

\section{Conclusions}

The Shada Mountains had 495 plant species belonging to 314 genera, 76 families, including 19 endemic species and 43 endangered species. The species richness in the Shada Mountains within an area of $69 \mathrm{~km}^{2}$ accounted for $22 \%$ of the total flora of Saudi Arabia. Frequency and abundance of species in the Shada Mountains were found to be controlled by physiographic features, particularly altitude and soil characteristics. The elevational zones ranging from 1001 to $1500 \mathrm{~m}$ a.s.l. were the highly concentrated belts for endemic and endangered species. All in all, herbarium and publications data on biodiversity hotspots can provide valuable information on species occurrences. Yet, detailed information on the altitude regimes of endemics and endangered species is vital for identifying small-scale hotspots and for prioritizing the conservation efforts. The outcomes of hyper-spaces from the perspective of latitude regimes can also provide a reference for studying the biodiversity of the other small-scale hotspots of mountain ecosystems.

\section{Acknowledgements}

The authors would like to express their sincere appreciation to the Deanship of Scientific Research at King Saud University for funding this research (RG-1437-002).

\section{References}

Alatar A A, El-Sheikh M A R, Thomas J, et al. 2015. Vegetation, floristic diversity, and size-classes of Acacia gerrardii in an arid wadi ecosystem. Arid Land Research and Management, 29(3): 335-359.

Allen S E, Grimshaw H M, Parkinson J A, et al. 1989. Chemical Analysis of Ecological Materials. London: Blackwell Scientific Publications, 285-344.

Beard J S, Chapman A R, Gioia P. 2000. Species richness and endemism in the Western Australian flora. Journal of Biogeography, 27(6): 1257-1268.

Braak C J F, Šmilauer P. 2002. CANOCO Reference Manual and CanoDraw for Windows User's Guide: Software for Canonical Community Ordination (Version 4.5). Ithaca: Microcomputer Power.

Brown J H. 2001. Mammals on mountainsides: elevational patterns of diversity. Global Ecology and Biogeography, 10(1): 101-109.

Chaudhary S A, Al-Jowaid A A A. 1999. Vegetation of the Kingdom of Saudi Arabia. Riyadh: Ministry of Agriculture and Water Press, 169-623.

Chaudhary S A. 1999-2001. Flora of the Kingdom of Saudi Arabia. Vols. I-III. Riyadh: Ministry of Agriculture and Water Press, 104-203, 255-241, 626-678.

Collenette I S. 1999. Wild Flowers of Saudi Arabia. Riyadh: National Commission for Wild Life Conservation and Development, 11-25.

Colwell R K, Hurtt G C. 1994. Nonbiological gradients in species richness and a spurious Rapoport effect. The American Naturalist, 144(4): 570-595.

Dewidar K H, Al Rehili B. 2013. Assessment of vegetation indices for estimating plant coverage and plant density in the Northern Sarawat Mountains, Saudi Arabia. Merit Research Journal of Agricultural Science and Soil Sciences, 1(2): 19-32.

El Karemy Z A R, Zayed K M. 1992. Distribution of plant communities across AlAbna escarpment, SW Saudi Arabia. Phyton, 32: 79-101.

El-Shikh M A. 2005. Plant succession on abandoned fields after 25 years of shifting cultivation in Assuit, Egypt. Journal of Arid Environments, 61(3): 461-481.

El-Sheikh M A. 2013. Population structure of woody plants in the arid cloud forests of Dhofar, southern Oman. Acta Botanica Croatica, 72(1): 97-111.

El-Sheikh M A, Thomas J, Alatar A A, et al. 2013. Vegetation of Thumamah Nature Park: a managed arid land site in Saudi Arabia. Rendiconti Lincei, 24(4): 349-367.

Forsskål P. 1775. Flora Aegyptiaco-Arabica. Denmark: Copenhagen, 1-519.

Gentry A H. 1986. Endemism in tropical versus temperate communities. In: Soulé M E. Conservation Biology: The Science of 
Scarcity and Diversity. Sunderland, Massachusetts: Sinauer Associates, 153-181.

Ghazanfar S A, Fisher M. 1998. Vegetation of the Arabian Peninsula. London: Kluwer, 88-192.

Hall M, Scholte P, Al-Khulaidi A W, et al. 2009. Arabia's last forests under threat II: remaining fragments of unique valley forest in southwest Arabia. Edinburgh Journal of Botany, 66(2): 263-281.

Hall M, Llewellyn O A, Miller A G, et al. 2010. Important plant areas in the Arabian Peninsula: 2 Farasan Archipelago. Edinburgh Journal of Botany, 67(2): 189-208.

Hall M, Miller A G, Llewellyn O A, et al. 2011. Important plant areas in the Arabian Peninsula. 3. 'Uruq bani Ma' arid. Edinburgh Journal of Botany, 68(2): 183-197.

Hegazy A K, El-Demerdash M A, Hosni H A. 1998. Vegetation, species diversity, and floristic relations along an altitudinal gradient in south-west Saudi Arabia. Journal of Arid Environments, 38(1): 3-13.

Llewellyn O A, Hall M, Miller A G, et al. 2010. Important plant areas in the Arabian Peninsula: 1. Jabal Qaraqir. Edinburgh Journal of Botany, 67(1): 37-56.

Llewellyn O A, Hall M, Miller A G, et al. 2011. Important plant areas in the Arabian Peninsula. 4. Jabal Aja'. Edinburgh Journal of Botany, 68(2): 199-224.

Magurran A E. 1988. Ecological Diversity and Its Measurement. Princeton: Princeton University Press, 101-121.

Major J. 1988. Endemism: a botanical perspective. In: Myers A A, Giller P S. Analytical Biogeography: An Integrated Approach to the Study of Animal and Plant Distributions. London: Chapman \& Hall, 117-146.

Migahid A M. 1978. Flora of Saudi Arabia, Vol. 2 (2 $2^{\text {nd }}$ ed.). Riyadh: Riyadh University, 70-596.

Miller A G, Nyberg J. 1991. Patterns of endemism in Arabia. Flora et Vegetatio Mundi, 9: 263-273.

Ojeda F, Marañón T, Arroyo J. 2000. Plant diversity patterns in the Aljibe Mountains (S. Spain): a comprehensive account. Biodiversity \& Conservation, 9(9): 1323-1343.

Pielou E C. 1975. Ecological Diversity. New York: John Wiley, 37-48, 135-145.

Ratnaweera P B, de Silva E D, Williams D E, et al. 2015. Antimicrobial activities of endophytic fungi obtained from the arid zone invasive plant Opuntia dillenii and the isolation of equisetin, from endophytic Fusarium sp. BMC Complementary and Alternative Medicine, 15(1): 220.

Roberts C M, McClean C J, Veron J E N, et al. 2002. Marine biodiversity hotspots and conservation priorities for tropical reefs. Science, 295(5558): 1280-1284.

SPSS. 2006. SPSS Base 15.0 User Guide. Chicago: SPSS Inc.

Thomas J, Sivadasan M, Al-Ansari A M, et al. 2014. New generic and species records for the flora of Saudi Arabia. Saudi Journal of Biological Sciences, 21(5): 457-464.

Thomas J, Basahi R, Al-Ansari A E, et al. 2015. Additions to the Flora of Saudi Arabia: two new generic records from the Southern Tihama of Saudi Arabia. National Academy Science Letters, 38(6): 513-516.

Thomas J, El-Sheikh M A, Alfarhan A H, et al. 2016. Impact of alien invasive species on habitats and species richness in Saudi Arabia. Journal of Arid Environments, 127: 53-65.

Thulin M. 1993. Flora of Somalia. Kew: Royal Botanic Gardens, 125-186, 254-259, 273-459.

van der Werff H, Consiglio T. 2004. Distribution and conservation significance of endemic species of flowering plants in Peru. Biodiversity and Conservation, 13(9): 1699-1713.

Vetaas O R, Grytnes J A. 2002. Distribution of vascular plant species richness and endemic richness along the Himalayan elevation gradient in Nepal. Global Ecology and Biogeography, 11(4): 291-301.

Whittaker R J, Araújo M B, Jepson P, et al. 2005. Conservation Biogeography: assessment and prospect. Diversity and Distributions, 11(1): 3-23.

Wood J R I. 1997. A Handbook of the Yemen Flora. Kew: Royal Botanic Gardens, 80-81, 131-265, $273-321$.

Zhang Y B, Ma K P. 2008. Geographic distribution patterns and status assessment of threatened plants in China. Biodiversity and Conservation, 17(7): 1783-1798. 